\title{
Hard-boiled homemakers: The individual and the dystopian urban in the Japanese anti-detective novel
}

\section{DAVID TAGLIABUE}

\section{Abstract}

This paper discusses the ways in which Japanese authors have engaged with the tropes of hard-boiled detective fiction in order to examine postcapitalist Japanese society. With reference to the extant framework on the relationship between hard-boiled fiction and the urban space, discussion will focus on two Japanese novels: Natsuo Kirino's Out (アウト, 1997), and Haruki Murakami’s Dance Dance Dance (ダンス・ダンス・ダンス, 1983). Both texts depict individuals who have been displaced to the spatial and socioeconomic 'margins' of a dystopian urban space, and who, through narratives of crime and detection, attempt to escape its mundane oppression. However, both texts also challenge the hard-boiled genre through an integration of detective fiction archetypes with post-modern textual elements. Accordingly, they are emblematic of the emergent 'antidetective' novel, which denies the hermetic and cathartic aspects of the traditional crime novel to discuss irresolvable issues of modern identity. Nonetheless, whilst Dance uses surreal 'dream spaces' as a source of relief for its protagonist, Out instead ultimately critiques its own escapist fantasy through stark violence. Regardless, both texts argue personal autonomy can only be achieved by the rejection of the urban space itself for an arguably unattainable imaginary. 


\section{Introduction}

In the aftermath of World War II, the detective novel has been typically concerned at some level with what hard-boiled author Raymond Chandler termed 'the world you live in. ${ }^{1}$ More specifically, crime writers in the post-war period have increasingly engaged with the relationship between emergent urban capitalist societies and the individuals residing within them as a source of narrative conflict and mystery. Indeed, the genre itself arguably thrives on the anxieties derived from the processes of modernisation and homogenisation inherent to the emergence of culturally and economically hegemonic metropolises in the post-war period. ${ }^{2}$ These processes disrupt existing social and economic structures, and act upon the individual as forces of displacement and alienation, in some instances motivating criminal action.

In the developed world, nowhere outside the United States has this experience been as significant as Tokyo, the world's largest city and a major centre of the unprecedented expansion of both the Japanese and the global consumer societies of the post-war period. Correspondingly, this essay will examine the ways in which Japanese authors have developed the tropes of hard-boiled detective fiction in order to problematise elements of post-capitalist Japanese society. With reference to the extant framework on the relationship between hard-boiled fiction and urban space, discussion will focus on two prominent crime novels of the late twentieth century: Kirino Natsuo's Out (アウト, 1997), and Haruki Murakami’s Dance Dance Dance (ダンス・ダンス・ダンス, 1983). Both texts depict individuals who have been displaced to the spatial, economic and social 'margins' of a dystopian urban space, and who thus, through respective narratives of crime and detection, attempt to escape or transcend the mundane oppression of their daily lives.

However, it will also be argued that the texts transcend the delineated borders of the hard-boiled genre, synthesising the archetypal features of detective fiction with post-modern narrative elements. In this way, they contribute to the recent trend of the 'anti-detective' novel, which withholds the hermetic and cathartic aspects of the traditional crime novel in order to represent open-ended issues of modern identity. Nevertheless, whilst Dance engages with the surreal 'other' to provide personal resolution for its protagonist, Out instead critiques its own escapist fantasy through stark violence. Subsequently, both texts suggest that it is only through the rejection of the urban space itself for a perhaps unattainable imaginary that the individual can truly achieve personal autonomy.

1 Raymond Chandler, The Simple Art of Murder (Boston: Houghton Mifflin, 1950), www.en.utexas.edu/amlit/ amlitprivate/scans/chandlerart.html, accessed 17 April 2016.

2 Sari Kawana, Murder Most Modern: Detective Fiction and Japanese Culture (Minneapolis: University of Minnesota Press, 2008), 29-33. 


\section{Shovelling cultural snow}

Maeda Ai has argued that despite the ostensibly utopian designs of its economic modernisation, Tokyo, 'which display[s] such a brilliant outer surface, maintain[s] another unsightly face ... a dismal space proliferating unceasingly behind this façade ... factories as black boxes ... and the slum areas abandoned to decrepit conditions'. ${ }^{3}$ These spaces, hidden on the periphery of the urban, nonetheless are marshalled in support of the consumer habits of the urban centre; in this sense, the individuals who are relegated to the margins assume a 'recessive, secondary position in society' regulated by a monotonous routine of production, consumption, and unrequited ambition. ${ }^{4}$

Both Dance and Out depict individuals who have been denied entry to or rejected from the urban centre and who are thus relegated to supporting a self-reflexive narrative of production and consumption, both in the workplace and the domestic sphere. For these individuals, the urban assumes the characteristics of a dystopia, replete with economic and social institutions that serve to oppress the selfactualisation of the individual. Subsequently, both texts seek to undermine this narrative through the tropes of the detective novel, including not only the figure of the hard-boiled detective, but also the professional criminal. The use of generic features in both texts thus provides a controlled space for the discussion of postcapital anxieties and the suggestion of alternative conceptions of the individual's place in urban society. ${ }^{5}$

Kirino Natsuo's novel Out is intimately concerned with the depiction of the outer fringes of urban Japan and the alienation of the individuals who inhabit these peripheral and dystopian zones of post-industrial capitalist society. The novel focuses on four female friends who work an oppressive night shift in a decrepit satellite suburb of Tokyo, packaging bento boxes at a factory largely 'indistinguishable ... from a prison [where] private conversation ... was discouraged, and your bodily functions ... monitored'. ${ }^{6}$ Masako is a hardworking and stoic former financier; Yoshie, a destitute widow who looks after her incontinent mother-in-law; Kuniko, heavily in debt over her addiction to luxury items; and Yayoi is a new mother whose increasingly abusive husband has depleted their savings through gambling. When Yayoi spontaneously murders her husband

3 Ai Maeda, 'Utopia of the Prisonhouse: A Reading of In Darkest Tokyo', trans. Seiji M. Lippit and James A. Fuji, in Text and the City: Essays on Japanese Modernity, ed. Rey Chow, H.D Harootunian, and Masao Miyoshi (Durham and London: Duke University Press, 2004), 33.

4 Masao Yamaguchi, Bunka to Ryougisei (Chiyoda: Iwanami Shoten, 1975) quoted in A. Maeda, 'Utopia of the Prisonhouse: A Reading of In Darkest Tokyo', trans. Seiji M. Lippit and James A. Fuji, in Text and the City: Essays on Japanese Modernity, ed. Rey Chow, H.D Harootunian, and Masao Miyoshi (Durham and London: Duke University Press, 2004), 51.

5 Amanda Seaman, Bodies of Evidence: Women, Society, and Detective Fiction in 1990s Japan (Honolulu: University of Hawaii Press, 2004), 7.

6 Natsuo Kirino, Out, trans. S. Snyder (New York: Vintage Books, 2004), 464. 
in a fit of rage, first Masako then the other two women are persuaded into helping her dispose of the corpse and avoid the scrutiny of the police with the promise of monetary recompense.

The Tokyo thus depicted in Out is not the vibrant neon world characteristic of typical Western representations, but rather one located in the margins of this metropolis, which 'renders, in the form of physical lived space, the social marginalisation of the novel's main characters, each of whom has been excluded from the urban "centres" of power, wealth, and influence by the attitudes, actions, or absence of men'. ${ }^{7}$ In the urban space, each of these women, neither young nor traditionally beautiful, are forced by material circumstance to straddle spaces of production and domesticity, each largely mediated by masculine hierarchies, but are correspondingly denied acceptance in either socioeconomic space, leading them to acts of criminality as a means for self-sufficiency. ${ }^{8}$

Masako in particular embodies this tension. Working diligently for 22 years at a credit company, Masako is driven to ask for a raise when she discovers that her male contemporaries earn significantly more than her for equivalent work. As a result, she is subject to the harassment of her male peers, 'constantly after her ... as a result she found it difficult to get her own work done and ended up putting in even more overtime. Inevitably, the quality of her work suffered, and this was reflected in poor evaluations ... [which] meant ... that she was ineligible for promotion'. ${ }^{9}$ Subsequently, after both being verbally and physically abused by her boss for exposing a mistake he has made, Masako, due to her threatening status as an industrious older woman, is economically and socially marginalised. Indeed, when the bursting of the credit bubble leads to a merger of the company with another firm, Masako is forced into retirement, to the desultory applause of her fellow workers. Through this depiction, Kirino engages with a broad culture of gender-based oppression in the Japanese workspace to depict the dystopian aspects of the modern urban.

Nevertheless, Masako is also denied power in the domestic sphere, in which her once nuclear family has been atomised by an unspoken decision to 'shoulder their own separate burdens and inhabit their own isolated reality'. ${ }^{10}$ She and her husband no longer share a bed and live almost entirely separate lives due to their alternate working hours, and her son, a college dropout, refuses to even acknowledge her, except to eat her cooking. Subsequently, Masako is alienated from her own home; taking up a job at the bento factory despite the economic solvency of her family, she admits that "lately she felt more at home in a scoured bathroom than a busy,

7 Amanda C. Seaman, 'Inside OUT: Space, Gender, and Power in Kirino Natsuo', Japanese Language and Literature, Vol. 40, No. 2 (Oct. 2006): 201, doi: 10.2307/30198010, accessed 17 April 2016.

8 Seaman, 'Inside OUT', 201.

9 Kirino, Out, 202.

10 Kirino, Out, 65. 
homey kitchen. ${ }^{11}$ In this way, Masako's lack of personal agency is connected to gendered narratives of public and private urban space in modern Japanese society. This forces her to unsuccessfully balance her work and home life, leading to a sense of alienation and apathy.

Correspondingly, Masako's assumed role as a professional criminal who cuts up bodies for money, functions to control these two spaces of production and domesticity on her own terms. This is evident in the nature of the crime itself, described by Imai, the detective investigating the murders, as a practical yet also almost domestic act: 'women [cut up bodies] ... because they can't carry [them] whole ... with all the time they spent in the kitchen, no doubt women were more used to dealing with meat and blood'. ${ }^{12}$ Indeed, whilst cutting up bodies, Masako and her companions wear aprons and use sashimi knives. Masako's domestic experience, now directed towards crime, 'allows her reentry into the public sphere as having a recognized skill (albeit non-traditional)—one which allows her to make significant money'. ${ }^{13}$ By turning dismemberment into a business over which she has a certain amount of executive control (one conducted out of her own bathroom, no less), Masako gains a modicum of autonomy over the production of capital by engaging with aspects of her own domesticity. Kirino thus cultivates the trope of the professional criminal, using the liberation inherent to crime in order to challenge the sanctity of oppressive social norms.

Conversely, Haruki Murakami's Dance Dance Dance positively engages elements of middle-class domesticity in constructing a hard-boiled detective story that nonetheless similarly considers the oppressive relationship between the urban centre and the individual. In Dance, acts of domestic minutiae assume a kind of escapism for the novel's unnamed protagonist, and therein function as a resistance to his alienation as a member of an 'advanced capitalist' society, represented most pointedly by the lush, cosmopolitan Dolphin Hotel in Sapporo, which the protagonist visits a number of times over the course of the novel. The hotel, standing on the site of an earlier and more decrepit hotel also named the Dolphin, is in many respects representative perhaps of the encroachment of the consumer culture of 1980s Japan on older and more personal modes and sites of social interaction:

the area had changed markedly from the old days ... Stores were boarded up ... all kinds of new establishments had popped up one after the next, pushing aside the dingy old three-story blockhouses ... with traditional noren entrance curtains. Build a hotel of that scale ... and the balance is upset. The flow of people changes ... Land prices go up. ${ }^{14}$

11 Kirino, Out, 188.

12 Kirino, Out, 270.

13 Seaman, 'Inside OUT', 209.

14 Haruki Murakami, Dance Dance Dance, trans. A. Birnbaum (London: Vintage Books, 2003), 30. 
In this sense it is fitting that the protagonist, a middle-aged male living in Shibuya, is himself employed as a freelance writer for a number of consumer magazines for women, 'shovelling ... cultural snow' ${ }^{15}$ through the meticulous if somewhat banal process of researching and categorising restaurants for 'best of' lists. In a way perhaps similar to the characters in Out, he is burdened with the jobs that had no takers ... [at] the junkyard at the edge of town. ${ }^{16}$ The protagonist is thus a figure whose creative aspiration has been reined in by the necessity of a pay-check:

with not one speck of ambition ... my only concern was to do things systematically, from one end to the other ... who was I to complain about waste? We live in an advanced capitalist society ... Waste is the name of the game ${ }^{17}$

Nevertheless, the protagonist simultaneously functions as

a unique yet readily recognizable variation on Chandler's detective ... Murakami's Japanese middle-class Everyman remains strangely unconcerned with money, career, or social prestige ... [He] derive[s] pleasure from the minutiae of small household chores, like ironing a shirt or cooking pasta-activities that are explicitly coded as domestic or feminine'. ${ }^{18}$

The protagonist of Dance is preoccupied by series of domestic tasks, most notably as the caretaker for Yuki, a precocious teenager whose wealthy and self-absorbed parents have largely abandoned her to a similar life on the margins of society. In contrast to Out, the domestic space and its associated lifestyles thus represent a certain liberating salience for the protagonist, rather than acting as a space of oppression. This is, as Leonard Cassuto argues, consistent with the trope of the hard-boiled detective itself, which in the post-war period has increasingly engaged with narratives of sentimentality and domesticity in order to reflect the social realities, including broken families and the fragmentation of personal relationships, of an increasingly urbanised consumer culture. ${ }^{19}$

The protagonist's embodiment of this role is evident in his relationship with Gotanda, a former schoolmate and now famous actor, with whom he reconnects whilst tracking down a former lover who has disappeared in mysterious circumstances. Gotanda himself is an agent of urban oppression: connected to a nebulous organisation of powerful Tokyo businessmen that contracts prostitution, Gotanda plays some unresolved role in the disappearance and death of a number

15 Murakami, Dance Dance Dance, 7.

16 Murakami, Dance Dance Dance, 13.

17 Ibid, 12.

18 Stephen Hantke, 'Postmodernism and Genre Fiction as Deferred Actions: Haruki Murakami and the Noir Tradition,' Critique, Vol. 49, No. 1 (Fall 2007): 6, doi: 10.3200/CRIT.49.1.2-24, accessed 17 April 2016.

19 Leonard Cassuto, Hard-Boiled Sentimentality: The Secret History of American Crime Stories (New York: Columbia University Press, 2009), 5. 
of call girls, each with emotional significance to the protagonist. Nevertheless, despite his privilege as a member of the urban elite, he is also a victim of restricting standards of masculine identity and consumerism, describing himself as:

[a] life-size dress up doll. Sewed together with loans and mortgages ... I live in a jet-stream condo ... I have this Patek-Philippe watch-a step up from Rolex, y'know? ... But the worst thing is ... as long as I keep living like this, I can't get what I want ... love. And tranquillity. And a healthy family. And a simple life. ${ }^{20}$

By eliciting these confessions from Gotanda, the protagonist fulfils Cassuto's detective archetype and, in contrast to Out, exposes an element of passive resistance to the urban through the characters' shared desire for a life of domestic contentment.

\section{Caught up in a dream}

Both Out and Dance invest in the tropes of the detective novel in order to present similar, if ultimately contrasting, depictions of the dystopian influence of the urban environments of post-capitalist Japan. Nevertheless, both texts also engage to a varying extent in the post-modern inversion of the genre; namely, both avoid the self-contained resolution of the mystery, relegating it to the periphery of the narrative for the sake of other thematic concerns. In this way, they act, as Rebecca Suter attests, as instances of the 'anti-detective novel', a post-war phenomenon where the 'strictly criminal element disappears, the detective is replaced by [the] writer, and the focus shifts to the relationship between writer, reader and text'. ${ }^{21}$ In this way, the traditionally linear sequence of clues become part of an open and irresolute dialogue, allowing for the subjective interpretation of the reader. ${ }^{22}$ Nevertheless, as will be seen, this device is used in each text in contrasting ways; whereas Dance heightens the surreal in the search for the self, Out instead uses the anti-detective to reinforce a brutal social realism.

Indeed, Out readily engages with themes of crime in the urban space to critically examine the roles and rights of the individual, particularly women, in modern Japan. Nevertheless, it is arguable that this depiction also reinforces the difficulty for the individual to substantially challenge the oppressive status quo of Japanese society. Masako's narrative is ultimately one of escape, as she is tracked down by Satake, the former yakuza initially implicated in the murder of Yayoi's husband, and brutally raped until she manages to kill him and, it is suggested, flee to a new life in Brazil with Yayoi's insurance money. It is notable that in this iteration of the detective

20 Murakami, Dance Dance Dance, 290.

21 Rebecca Suter, The Japanization of Modernity: Murakami Haruki between Japan and the United States (Cambridge: Harvard University Press, 2008), 104.

22 Stefano Tani, The Doomed Detective: The Contribution of the Detective Novel to Postmodern American and Italian Fiction (Carbondale: Southern Illinois University Press, 1984), 200. 
novel, the female protagonists, despite reacting to the oppression inherent to their environment, are regardless positioned within the narrative as criminal outsiders. Concurrently, it is men, including the aforementioned inspector Imai, but also more problematically Satake himself, that represent the urban spaces of the state and the city centre respectively as 'detectives', reinforcing the subordination and objectification of the women with a certain amount of social and legal sanction.

Indeed, Satake even commissions an investigation agency to collect meticulous data on the women, constructing an intricate revenge fantasy involving murder and sexual violence that simultaneously fulfils and perverts the trope of private eye as an agent of society's values. He is thus simultaneously threatened and intrigued by the actions of Masako; nevertheless, his response is to subvert her act of selfassertion through kidnap, rape and attempted murder. This response is once again anchored in conceptions of gendered space, as:

Satake is able to subvert [Masako's] process of de-gendering, forcefully identifying her with ... her sex. Moreover, by staging the rape on a conveyor belt like the one in the bento factory ... he literally 'puts her in her place'-that of food and production, rather than money and commerce. ${ }^{23}$

Nevertheless, more problematic, perhaps, is Masako's ostensible psychological submission to this act of violation and subjugation, which seemingly gives an amount of credence to Satake's actions and worldview: 'She gave a small moan ... wishing she could see him one more time ... Maybe she would find another man like him, and pursue his dream?'24 Kirino here seeks to suggest that this sexual violence motivates not only Masako's assertive response against Satake, but also an amount of sexual liberation, and thus functions as Masako's ultimate transition into the urban zone: 'This was Satake's town, a chaotic and steamily hedonistic place. The door she had opened when she went to work on the night shift had led here, to a place she'd never known before ....'. ${ }^{25}$ However, though this self-actualisation comes with the realisation that 'she couldn't live her life as someone's prisoner ... caught up in a dream of the past ... forced to dig down inside oneself', ultimately this lack of resolution seems to suggest that Masako can only ultimately flee her oppression, rather than confront it entirely. ${ }^{26}$

Furthermore, Masako's ability to escape the gendered power of the urban space is at odds with the narratives of the other women, who are trapped within permanent cycles of subordination. Kuniko, for instance, is a victim of negative body-image and obsessive consumption, which has led her into an insurmountable amount of debt: 'the credit line she'd run up decking herself out in clothes and accessories meant that she was still scrambling today ... the interest alone was now so crushing

23 Seaman, 'Inside OUT', 212-213.

24 Kirino, Out, 519.

25 Kirino, Out, 519.

26 Kirino, Out, 520. 
that she had no idea whether she was even paying off the principal any more ....27 Kuniko's indoctrination into a capitalist narrative of feminine behaviour and her resultant obsession with being sexually desirable brings her to other misfortune; enamoured by Satake's advances, she is murdered and sent to Masako's business for dismemberment. Kirino does not through her narrative of criminal agency provide substantive alternatives to patterns of social and economic oppression, suggesting instead that such avenues do not exist within the boundaries of normal society.

On the other hand, Dance is concerned with the identification of an individual space within the homogeneity of urban society. Key to this narrative conceit is Murakami's characteristic engagement with the surreal and the creation of a shared dream space that connects and unifies his seemingly disparate characters in deeply personal and cathartic ways. As Susan Napier suggests, 'by using a few fantastic touches, Murakami creates extraordinary vivid "other worlds" characterized by dreams, ghosts, and magic that still speak eloquently of contemporary Japan'. ${ }^{28}$ In Dance, this space takes the form of a mysterious floor within the ultra-modern l'Hotel Dauphin in Sapporo, which functions as a conduit between the real world and another world inhabited by the 'Sheep-man', who serves as a cryptic spirit guide for the protagonist. This zone is visited not only by the protagonist, but also his aforementioned teenaged ward, Yuki, and Yumiyoshi, a concierge at the hotel and the protagonist's eventual love interest.

The world of the 'Sheep-man', imbued with the spirit of the earlier Dolphin, mirrors the domestic space for the protagonist as a site of individuality and escape from the homogenous urban. As the Sheep-man remarks: 'This is your world ... If you're seeking it, it's here. The place was put here for you ... Special ... To keep things from falling apart. To keep you from forgetting. ${ }^{29}$ This dialogue has cathartic significance for the protagonist, allowing him to examine himself and his sense of ennui:

I poured out the story of my life ... How I managed to support myself. Yet never managed to go anywhere ... How nothing touched me. And I touched nothing ... How I worked like a fool for things that didn't [matter] ... How I barely made the connection to this place. This place I didn't know but had this feeling that I was part of ... that maybe I knew ... I belonged to. ${ }^{30}$

As Hantke contends, the dream space of Dance and its connection to the spirit of the old Dolphin Hotel as a place of belonging thus fulfils the role of a common trope of noir literature:

27 Kirino, Out, 19-22.

28 Susan Napier, The Fantastic in Modern Japanese Literature (London and New York: Routledge, 1996), 207.

29 Murakami, Dance Dance Dance, 84.

30 Murakami, Dance Dance Dance, 82-83. 
the motif of the spatial other ... the existence of a space outside the [claustrophobic and deterministic] noir universe ... [which] serves as an object of utopian desire ... for characters weighed down by existential pressures, chafing against urban grittiness, and suffering from isolation and alienation. It is a place of vague memories or unfulfilled promises. In the attempt to escape, characters must cross the boundaries that encircle the noir universe. ${ }^{31}$

For the protagonist, this is achieved through a physical act of 'crossing' between worlds, both in his decision to join Yumiyoshi in Sapporo and thus take new control over his destiny, but also in their shared act of confronting the horror of the 'other world' within the dream space, ostensibly the world of the dead, by passing through a wall in the Sheep-man's office, where:

time wavered ... gravity lost its force. Memories, old memories, like vapour, wafted up. The degeneration of my flesh accelerated. I passed through the huge, complex knot of my own DNA ... My body decomposed, blew apart—and was whole again. ${ }^{32}$

This act is one of renewal in which the protagonist is washed clean of the burden of his past and is thus able to look towards the future.

This 'other world' thus functions as Hantke's border between the oppressive urban space, replete with painful memories and inhibiting ties, and the protagonist's liberation and self-actualisation. Nevertheless, it also constitutes a source of narrative mystery. Indeed, entering a similar fugue during a trip to Hawaii, the protagonist encounters:

six skeletons in all ... All sat in natural positions. One man ... had his line of vision fixed on a television. Another was bent over a table still set with dishes, the food now dust. Yet another, the only skeleton in an imperfect state, lay in bed. Its left arm was missing from the shoulder. ${ }^{33}$

These figures seemingly correlate to a number of people with whom the protagonist has interacted, and who have all suffered mysterious death or disappearance; nevertheless, the significance of this experience and of their deaths is never truly resolved. In this way, it is evident that Murakami seeks to disable the reader's expectations of the detective narrative as a self-contained space, and thus enables a more open-ended, if ultimately surrealistic, approach to themes of the self and society.

31 Hantke, 'Postmodernism and Genre Fiction', 11.

32 Murakami, Dance Dance Dance, 391.

33 Murakami, Dance Dance Dance, 271. 


\section{Conclusion}

Japanese authors in the post-war period have creatively engaged with and developed the literary tropes of the detective genre in order to problematise elements of modern urban society. Namely, these authors, including Haruki Murakami and Natsuo Kirino, have inverted the typical tropes of the genre to reflect the changing roles and responsibilities of the individual in the cities of contemporary Japan. Each author has nonetheless taken a different approach; where Murakami's stoic hard-boiled protagonist is largely concerned with the rectification of domestic and psychological disharmonies through the transformative power of the surreal 'other', the females in Kirino's Out use criminal acts to assert their economic and social independence.

Correspondingly, such treatments investigate the ways in which the emergent dominance of capitalist centres of consumption have formed new spaces, both domestic and industrial, on the fringes and in the hidden spaces of society, in which individual narratives of power and agency have been adapted and redeveloped to allow individuals the chance for self-actualisation but which also largely serve to reinforce a dystopian status quo replete with issues of sexual violence and socioeconomic oppression. In this way, the ultimate value of this literature as an agent of practical change is questionable; nevertheless, the anti-detective novel arguably functions as an engaging critique of hegemonic narratives in the urban space.

\section{Bibliography}

Cassuto, Leonard. Hard-Boiled Sentimentality: The Secret History of American Crime Stories. New York: Columbia University Press, 2009.

Chandler, Raymond. The Simple Art of Murder. Boston: Houghton Mifflin, 1950, www.en.utexas.edu/amlit/amlitprivate/scans/chandlerart.html, accessed 17 April 2016.

Hantke, Steffen. 'Postmodernism and Genre Fiction as Deferred Actions: Haruki Murakami and the Noir Tradition.' Critique. Vol. 49, No. 1 (Fall 2007), 3-23, DOI: 10.3200/CRIT.49.1.2-24, accessed 17 April 2016.

Kawana, Sari. Murder Most Modern: Detective Fiction and Japanese Culture. Minneapolis: University of Minnesota Press, 2008.

Kirino, Natsuo. Out, translated by Stephen Snyder. New York: Vintage Books, 2004. 
Maeda, Ai. 'Utopia of the Prisonhouse: A Reading of In Darkest Tokyo', translated by Seiji M. Lippit and James A. Fuji. In Text and the City: Essays on Japanese Modernity, edited by Rey Chow, H.D Harootunian, and Masao Miyoshi, 21-64. Durham and London: Duke University Press, 2004.

Murakami, Haruki. Dance Dance Dance, translated by Alfred Birnbaum. London: Vintage Books, 2003.

Napier, Susan J. The Fantastic in Modern Japanese Literature. London and New York: Routledge, 1996.

Seaman, Amanda C. 'Inside OUT: Space, Gender, and Power in Kirino Natsuo.' Japanese Language and Literature. Vol. 40, No. 2 (Oct. 2006), 197-217, DOI: 10.2307/30198010, accessed 17 April 2016.

Seaman, Amanda C. Bodies of Evidence: Women, Society, and Detective Fiction in 1990s Japan. Honolulu: University of Hawaii Press, 2004.

Suter, Rebecca. The Japanization of Modernity: Murakami Haruki between Japan and the United States. Cambridge: Harvard University Press, 2008.

Tani, Stefano. The Doomed Detective: The Contribution of the Detective Novel to Postmodern American and Italian Fiction. Carbondale: Southern Illinois University Press, 1984. 
This text is taken from The ANU Undergraduate Research Journal, Volume Seven, 2015, edited by Daniel McKay, published 2016 by ANU eView, The Australian National University, Canberra, Australia. 